\title{
Are Lesser Snow Geese, Chen caerulescens caerulescens, Exceeding the Carrying Capacity of the Fraser River Delta's Brackish Marshes?
}

\author{
Mike W. Demarchi \\ LGL Limited, environmental research associates, 9768 Second Street, Sidney, British Columbia V8L 3Y8 Canada; e-mail: \\ demarchi@lgl.com
}

Demarchi, Mike W. 2006. Are Lesser Snow Geese, Chen caerulescens caerulescens exceeding the carrying capacity of the Fraser River delta's brackish marshes? Canadian Field-Naturalist 120(2): 213-224.

\begin{abstract}
Brackish marshes of the Fraser River delta provide important habitats for such high-profile animals as White Sturgeon (Acipenser transmontanus), Pacific Eulachon (Thaleichthys pacificus), Pacific salmon (Oncorhynchus spp.), Western Sandpiper (Calidris mauri), and Lesser Snow Goose (Chen caerulescens caerulescens), the latter comprising the "Fraser-Skagit" segment of the Wrangel Island (Russia) population. This study assessed whether the current numbers of Snow Geese are exceeding the carrying capacity of brackish marshes in the Fraser River delta. Simulation modelling predicts that those marshes are presently capable of supporting $\sim 17500$ Snow Geese-a value that is greatly exceeded by the numbers of geese that have over-wintered there in recent years ( 80000 in 2004-2005). The Pacific Flyway Council's target 3-y average population and segment sizes of 120000 and 50000 - 70000 , respectively, were set without considering the carrying capacity of natural wintering habitats, the potential impacts of too many geese on upland agriculture, or implications for hazards to civilian aircraft at Vancouver International Airport. The modelled results of the present study suggest that the Fraser River delta can sustain the current numbers of Snow Geese that stage or winter there only if those birds also forage in agricultural and refuge fields - a relatively recent phenomenon that likely bolstered the Snow Goose population. Over-use by Snow Geese can degrade the productivity and habitat quality of marshes. There is documented evidence that some key plant species (e.g., Scirpus americanus) of the brackish marshes of the Fraser River delta are well below their biomass potential $(\sim 15 \%)$, primarily because of grubbing by Snow Geese. Other species that depend on this brackish environment as well as human interests in the Fraser River delta may be adversely affected by an overabundance of Snow Geese. The future effectiveness of hunting as a primary means of population regulation is questioned.
\end{abstract}

Key Words: Lesser Snow Goose, Chen caerulescens caerulescens, American Three-square Bulrush, Scirpus americanus, brackish marsh, carrying capacity, Fraser River delta, bird strike, British Columbia.

The recent dramatic increase in numbers of the midcontinent (North America) Lesser Snow Goose (Chen caerulescens caerulescens) has attracted considerable attention - mainly because of the habitat degradation it has caused (e.g., Kerbes et al. 1990; Williams et al. 1993; Ankney 1996). Consumption of agricultural foods (which may be more abundant and contain higher fractions of metabolizable energy than native brackish-marsh plants) and a network of refugia are thought to have contributed to substantial increases in some North American populations of Lesser Snow Geese by improving overwinter survival (Ankney 1996; Jefferies 1997). Although the bird community that winters on the Fraser River delta contains many species of grazing waterfowl, the large amount of rhizome biomass consumed annually by Lesser Snow Goose (Boyd 1995) means it is potentially a keystone species there as it is elsewhere (e.g., Kerbes et al. 1990).

Many Snow Geese that breed on Wrangel Island (Russia) use the Fraser River delta as staging or wintering habitat between October and April (Subcommittee on White Geese 1992*; Boyd 1995; Pacific Flyway Council 2006*). They forage in brackish marshes of the Fraser River delta, primarily on rhizomes of American Three-square Bulrush (Scirpus americanus) and shoots of Lyngbei Sedge (Carex lyngbyei). J. P. Hatfield (personal communication, cited in Campbell et al. 1990) noted that Snow Geese began foraging in agricultural fields on the Fraser River delta in 1977. The number of Snow Geese using those fields rose from 2000 in the early 1980 s to between 20000 and 30000 in the 1990s (Boyd 1995; Canadian Wildlife Service et al. 1999*). The Canadian Wildlife Service (CWS) and local farmers actively enhance the Alaksen National Wildlife Area (ANWA) on Westham and Reifel islands in the Fraser River delta for wintering Snow Geese and other waterfowl. Fields within the ANWA are planted with crops to provide the birds with supplemental feed (Pacific Flyway Council 2006*).

Because Snow Geese and other grazing waterfowl can affect private agricultural fields outside the ANWA by consuming grass, crops, or crop residue such as corn and potatoes, and by altering surface-water drainage, the "Greenfields Program" administered by the Delta Farmland and Wildlife Trust (DFWT) was established in 1990. The goal of that program is to spread waterfowl impacts over a larger area, thereby lessening their severity in any one given area (Smith 1996*). The program encourages farmers to plant cover crops for soil conservation and provide forage for over-win- 
tering waterfowl. The costs of these cropping practices are shared among farmers, conservation societies, and government bodies.

Snow Geese that overwinter on the Fraser River delta are managed according to the Pacific Flyway Council's 2006 management plan (Pacific Flyway Council 2006*) which is a revised version of the 1992 plan (Subcommittee on White Geese 1992*). Although the overall Wrangel Island population target of 120000 birds (3year average) remains the same between the 1992 and 2006 plans, the target size of the Fraser-Skagit segment (also referred to as "subpopulation" or "flock") target was increased to a range of 50 000-70 000 birds in the 2006 plan. According to the 1992 plan, the segment target was a minimum 3-year average of 35000 birds. To achieve that, the ideal segment size had been identified to be between 30000 and 60000 birds (S. Boyd, personal communication). The historical size of the Wrangel Island population was considered when the goal was set, but some key factors were not: the carrying capacity of the Fraser and Skagit deltas, the possible impacts of Snow Geese on habitat quality and ecosystem function of the Fraser River delta, nor the possible impacts of Snow Geese on agriculture or airsafety. Under the 2006 plan, regulation of the Wrangel Island population is to occur by way of sport and subsistence hunting.

Burton (1977) concluded 30 years ago that the brackish marshes of the Fraser River delta would be damaged if the Fraser-Skagit segment exceeded 20000 Snow Geese. The purpose of this study was to evaluate, by way of simulation modelling, recent numbers of Snow Geese in light of the carrying capacity of the brackish marshes in the Fraser River delta.

\section{Study Area}

The Fraser River sustains the largest delta on Canada's Pacific coast. The delta covers $\sim 680 \mathrm{~km}^{2}$ of aquatic and terrestrial areas, stretching $30 \mathrm{~km}$ from New Westminster westward to Sand Heads Lighthouse and from Point Grey southward to the international boundary (Butler and Campbell 1987). Brackish marshes occupy $\sim 3 \%$ of the delta.

The Fraser River delta is a critical link in a series of migratory bird habitats along the Pacific Flyway between the arctic breeding grounds of North America and northeast Asia and wintering areas in southwestern North America, Central America, and South America. The delta supports some of the highest densities of wintering waterfowl, shorebirds, and raptors in Canada (Butler and Campbell 1987).

Brackish marshes of the Fraser River delta have evolved as a result of the interactions between the maritime conditions of the Pacific Ocean and the fresh water and sediment load of the Fraser River (Hutchinson 1982). Local tides are predominantly semidiurnal with a maximum range of $\sim 5 \mathrm{~m}$. The Fraser River is the largest river in British Columbia, with a mean an- nual flow of $3500 \mathrm{~m}^{3} / \mathrm{s}$. Eighty percent of the annual flow occurs during March to July (Hoos and Packman 1974, cited in Hutchinson 1982). Hutchinson (1982) divided the present brackish marshes of Lulu Island into three elevational zones: (1) low marsh-dominated by Scirpus americanus and S.maritimus; (2) middle marsh-dominated by Carex lyngbyei, Triglochin maritimum, and S. maritimus; and (3) high marsh-a community of Agrostis exerata, Potentilla pacifica, Distichlis spicata, and Typha latifolia.

Prior to dyking, the low elevations of much of the land near the western limit of the delta were subject to periodic flooding during spring freshet. Such flooding would have affected the delta's vegetation communities. Habitats of this area have been, and are heavily, modified by human activities. Although much of the Fraser River delta is used for agriculture, residential, commercial, and industrial developments are rapidly increasing at the expense of agricultural land-uses. Commercial greenhouse operations are increasingly replacing traditional field-based agriculture.

Much of the upland and foreshore areas of Reifel Island and Westham Island make up a wildlife sanctuary that is managed by the CWS. The sanctuary comprises 586 ha, of which 300 ha includes the federally owned ANWA that was designated a Ramsar site in May 1982 (Wetlands International, no date*). Approximately 410 ha of the sanctuary are in cultivated farmland. The adjacent George C. Reifel Refuge, initiated in the 1960s, consists of 400 ha of Crown land designated as a Migratory Bird Sanctuary under the Migratory Birds Convention Act of 1917.

Nearly 6000 ha in the municipality of Delta is used to produce vegetable crops and livestock. Of the cropland, nearly two-thirds is planted in vegetables such as potatoes, peas, beans, corn, pumpkins, cabbage, rutabagas. Hay fields, pasture, and corn silage represent more than one-quarter of the cropland on the delta. The remainder of the cropland on the delta is allocated to cereals and berries.

\section{Methods}

A map of the brackish marshes was prepared by digitally scanning colour air photos (1:24 000 scale) at high resolution and ortho-rectifying each photo by tying control points to those on a TRIM base-map (1:20 000 scale). Air photos from 18 September 1991 were deemed the best in terms of resolution, scale, date, season, and tide height. I. Hutchinson (personal communication) indicated that the brackish marsh profile has likely undergone very minor net changes since that time. Habitat polygons were digitized manually on-screen while viewing habitat features at various magnifications. The digital map upon which habitat calculations were made had a minimum resolution of 1:10 000. Small patches of Scirpus spp. near southwestern Sea Island were amalgamated because it was believed that the distribution of those plants had in- 
creased since the photos were taken (S. Boyd, personal communication). Interpretations of habitat type and zonation in the Fraser River delta were aided by information from Yamanaka (1975), Moody (1978), and Hutchinson (1982). Although changes in the marsh communities have undoubtedly occurred since maps in those reports were produced, the visual patterns of intertidal plant zonation were expected to have changed insignificantly. All mapping was done using the GIS programs MapInfo and ArcView.

Estimates of Snow Goose numbers since 1987-1988 were obtained from Boyd (1995) and Pacific Flyway Council $(2006 *)$. The numbers of Snow Geese using agricultural fields were obtained from Boyd (1995) for the period 1987-1992, and from Canadian Wildlife Service et al. (1999*) for the period 1995-1998. Data on the Greenfields Program were obtained from Smith (1996*).

Because of variation and error inherently associated with parameters used in the analyses, a stochastic simulation model was developed. The model, run in MS Excel 98, incorporated published and unpublished data from several sources. Data in Imperial units (e.g., kcal) were converted to SI units (e.g., kJ). Stochasticity was incorporated in the model by randomly selecting values that were within the $95 \%$ confidence limits, or hypothesized range of some parameters.

The model in Appendix 1 was used to estimate the carrying capacity of the brackish marshes in the first half of the overwintering period ("autumn", versus the second half of the overwintering period: "spring"). Because the Fraser River delta experiences substantially more Snow Goose-days during autumn than in spring (Boyd 1995) and has less autumn habitat than spring habitat (as mapped in this study), I assumed that any habitat-imposed limitations on the geese would occur in autumn. Each simulation first calculated the metabolizable caloric value of the available $S$. americanus. From that value, the number of supportable Snow Goose-days was determined. In turn, Snow Goose-days (y) were used to estimate the size of the Fraser-Skagit segment (x) by using the inverse of the linear relation: $\mathrm{y}=47.764(\mathrm{x})(P=0.028 ; r=0.89$; $\mathrm{df}=5$; y-intercept $=0$ ) between "autumn" Snow Goose-days on the Fraser River delta and the size of the Fraser-Skagit segment as calculated from data presented in Boyd (1995). The y-intercept of this equation was set at 0 to account for segment sizes lower than those presented in Boyd (1995). Five thousand simulations were run.

A lack of data on two issues may have implications for the accuracy of the model's results, but because the parameters represented by these issues would not affect the model in a unidirectional manner, their implications are not viewed as necessarily troublesome. First, Burton et al. (1979) suggested that Snow Geese feed almost exclusively on rhizomes of S. americanus during autumn. In fact, however, Burton (1977, page
17) stated that Snow Geese strongly prefer both $S$. americanus and S. paludosus (the latter also known as. S. maritimus). Unfortunately, as observed using gizzard contents, Burton (1977) could not differentiate between the cuticle reticulations of the rhizomes of the two species, thereby casting doubt on the accuracy of his conclusion about a dual food preference. Abundance of $S$. maritimus is about one-third that of $S$. americanus on the Fraser River delta (Yamanaka 1975). Second, the model assumes that all biomass grubbed by the Snow Geese is consumed by them. McIlhenny (1932; cited in Burton 1977) guessed that over-wintering Snow Geese in the southern United States rejected up to 10 times as much grubbed vegetation as they consumed. Burton (1977) felt that although some food rejection occurred on the Fraser River delta it did not likely approach those proportions.

\section{Results and Discussion}

Distribution, Abundance, and Carrying Capacity of Brackish Marshes in the Fraser River Delta

Autumn marsh habitat that is suitable for Snow Geese occurs in a narrow band along the western edge of the Fraser River delta's westernmost islands and near Brunswick Point (Figure 1). Most spring marsh habitat is similarly distributed. According to habitat mapping, the Fraser River delta contains 917.1 ha of "low marsh" habitat and 946.3 ha of "mid-high marsh" habitat in areas used by Snow Geese. Low marsh habitat is used by Snow Geese for "grubbing" bulrush rhizomes in the autumn period and mid-high marsh habitat is used in the spring for foraging on emergent sedges (Boyd 1995).

The results of autumn carrying capacity simulations of the Fraser River delta's brackish marshes are summarized in Figure 2. During autumn, brackish marshes can presently support a number of Snow Goose-days that is commensurate with a mean Fraser-Skagit segment size of 17600 geese (range 7400-35 000). Numbers larger than this will exceed the calculated carrying capacity of brackish marshes during most years. According to the model there was only a $1.4 \%$ chance that $>30000$ geese could be sustained by the brackish marshes (Figure 2). Those observations, and the conclusion that $S$. americanus biomass in the Fraser River delta is only $\sim 15 \%$ of what it might support in the absence of Snow Goose grubbing (Boyd 1995), suggest that brackish marshes are either already over-grubbed or are at considerable risk of being over-grubbed.

\section{Distribution and Abundance of Snow Geese on the Fraser River Delta}

Numbers of Snow Geese in the Fraser-Skagit segment have been estimated from aerial photos of geese on the Fraser and Skagit river deltas (Subcommittee on White Geese 1992*; Boyd 1995; Pacific Flyway Council 2006*). Most use of the Fraser River delta occurs during early October to mid-January ("autumn") and from late February to mid-April ("spring"). Al- 


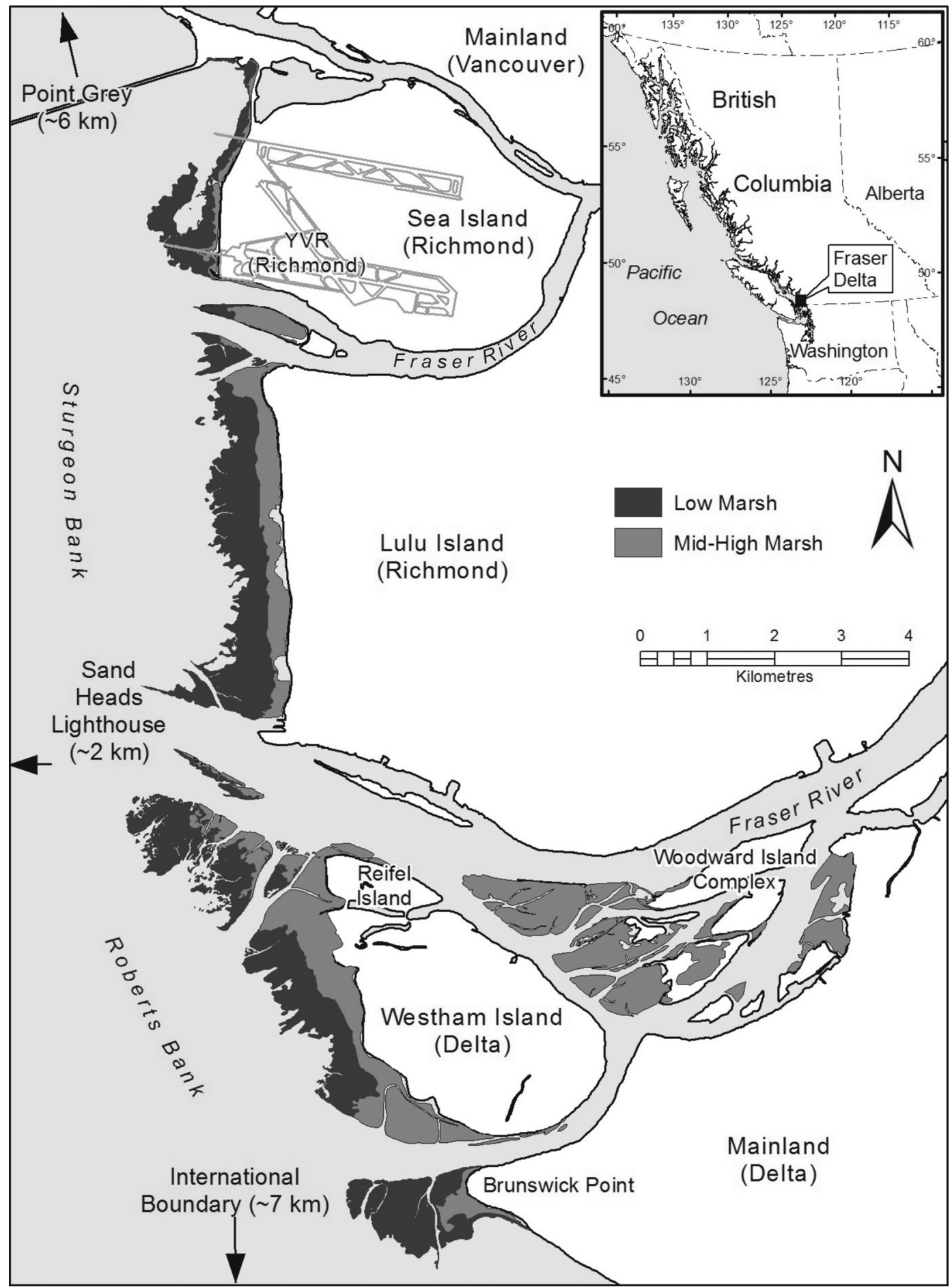

FIGURE 1. Distribution of intertidal marsh habitats used by Snow Geese during the autumn and spring periods on the Fraser River delta, British Columbia. Runways of the Vancouver international Airport (YVR) are indicated. 


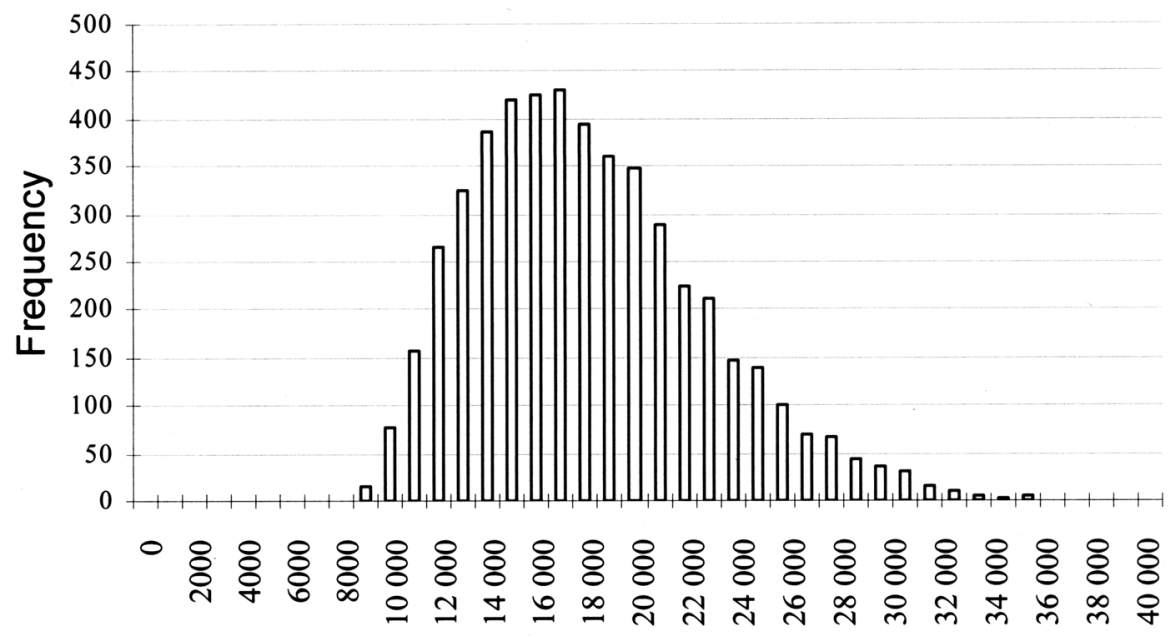

Fraser-Skagit Sub-Population Size (birds)

FIGURE 2. Simulation model results of the size of the Fraser-Skagit segment that could be supported by the brackish marshes of the Fraser River delta for Snow Geese during the autumn. 95\% confidence interval on mean: $17606 \pm 131(n=5000)$.

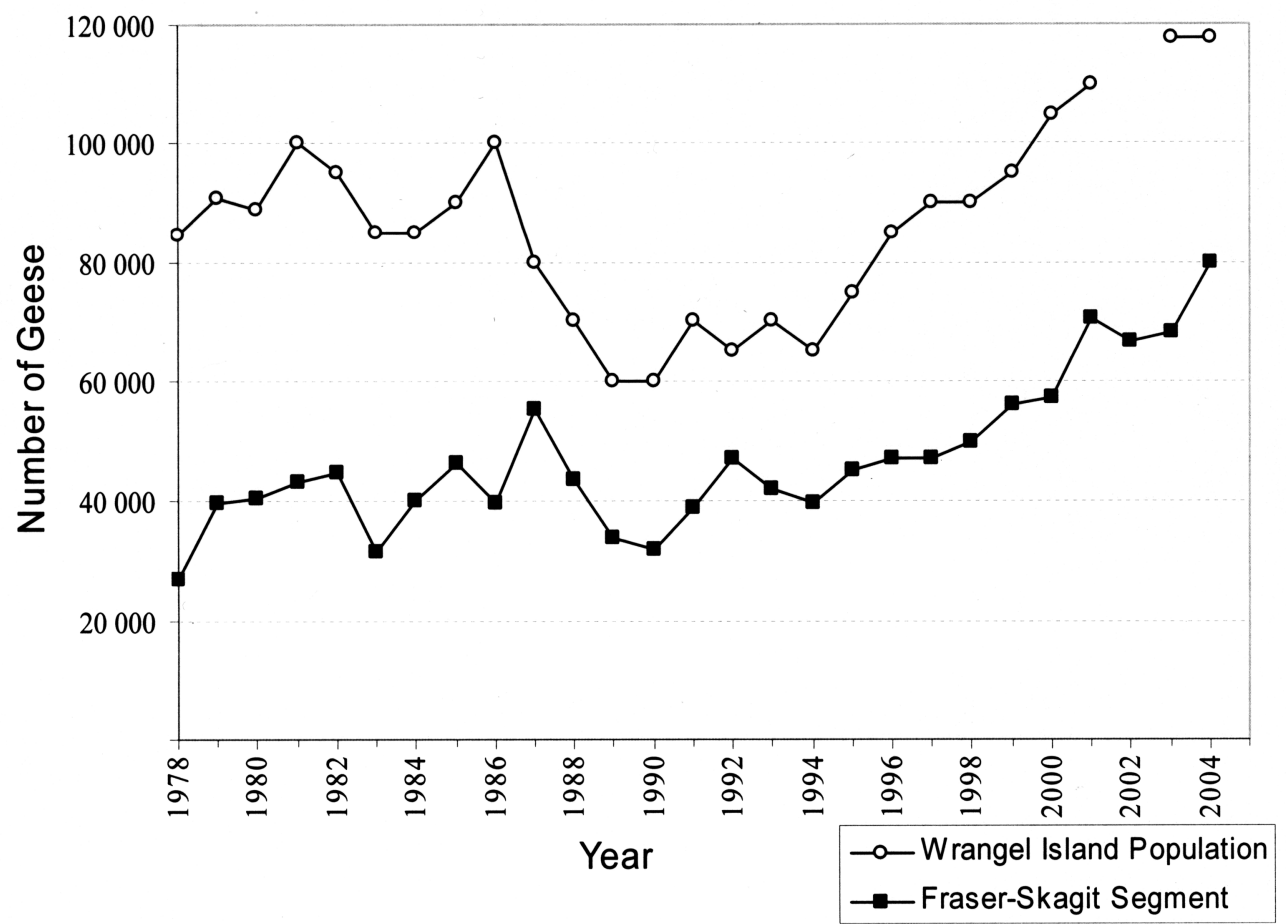

FIgURE 3. Estimates of the Wrangel Island Lesser Snow Goose Population size (total, spring) and size of the Fraser-Skagit segment (overwintering period beginning in year shown). Source: Pacific Flyway Council (2006*). 


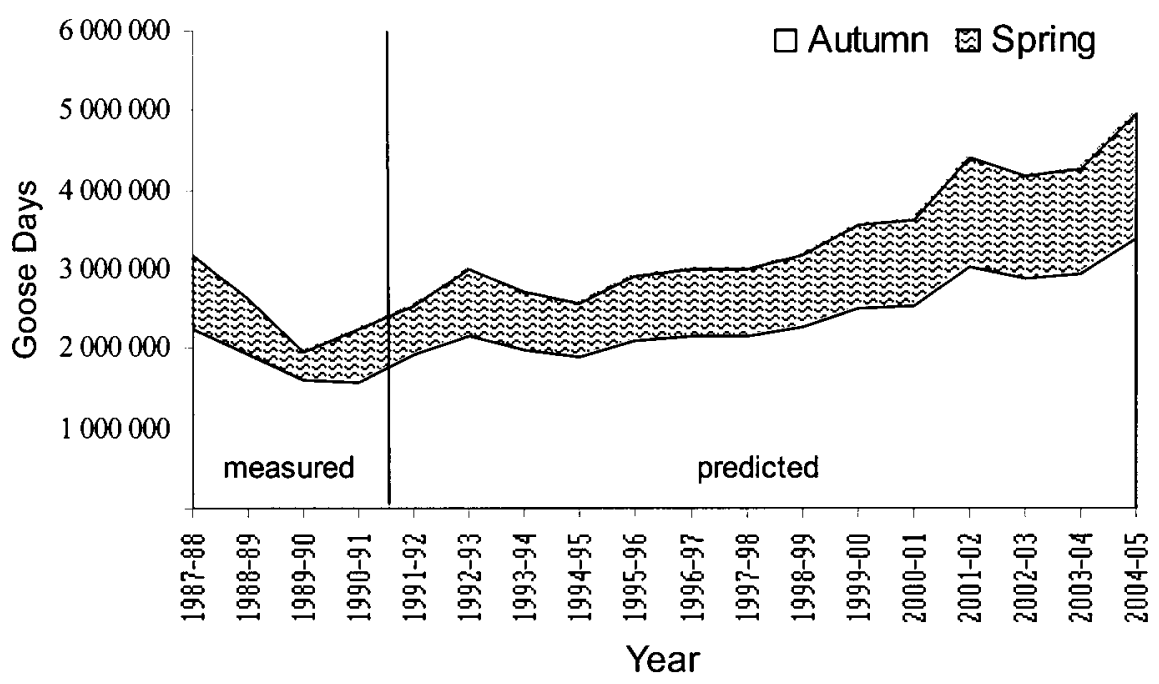

FIGURE 4. Stacked area chart showing measured and predicted number of Snow Goose-days on the Fraser River delta since 1987-1998. Data from 1987-1988 through 1991-1992 were measured by Boyd (1995). The remaining data were predicted using linear regression equations developed from data for the 1987-1988 through 1991-1992 period (Boyd 1995), and using population estimates (x values) from Pacific Flyway Council (2006*). Regression equations are as follows: (1) Autumn: $\mathrm{y}=36.4(\mathrm{x})+448977$ where $\mathrm{y}=$ autumn goose-days, and $\mathrm{x}=$ annual estimate of Fraser-Skagit segment $(P=0.016, r=0.94, \mathrm{df}=4)$. (2) Spring: $\mathrm{y}=22.7(\mathrm{x})-221987$ where $\mathrm{y}=$ spring goose-days, and $\mathrm{x}=$ annual estimate of Fraser-Skagit segment $(P=0.116, r=0.78, \mathrm{df}=4)$.

though geese occur on both deltas simultaneously during autumn and spring, most or all geese use the Skagit River delta for the four to five weeks between these periods. Since the winter of 1978-1979 (when the first photo counts on the Fraser and Skagit deltas were done) the Fraser-Skagit segment grew from $\sim 27000$ birds (Pacific Flyway Council 2006*). Owing to high juvenile production and survival rates of Snow Geese, the Fraser-Skagit segment increased 3- to 4-fold in the late 1970s (Boyd 1995). Numbers of Snow Geese fluctuated in the 1980s then increased thereafter (Figure 3 ). Figure 3 shows an upward trend in the size of the Fraser-Skagit segment from 1978 through spring $2005(P<0.001 ; r=0.76$; df $=26)$. Recent surveys indicate that during the winter of 2004-2005 the segment was the highest ever recorded at $\sim 80000$ birds (Pacific Flyway Council 2006*). From 1987-2005 the Fraser River delta sustained an estimated 2-5 million goose-days annually (Figure 4).

Farm fields apparently play an increasingly important role in the over-wintering ecology of the FraserSkagit segment of Snow Geese. The percentage of Snow Goose days spent on upland fields between 19871988 and 1991-1992 varied among years (Figure 5), but autumn-use, ranging between $7 \%$ and $30 \%$, was typically much greater than spring use, which ranged from 0\% to 20\% (Boyd 1995). Although surveys of use of agricultural fields on Westham Island were conducted via ground counts from autumn 1995 through spring
1998 (cf. photo counts up to that point), the use of farm fields has increased in recent years. From 1995-1996 through 1997-1998, the use of farm fields on Westham Island (representing $~ 90 \%$ of all use of upland fields (S. Boyd, personal communication) ranged between $17 \%$ and $46 \%$ of the total number of goose days spent on the Fraser River delta in the autumn, and increased from $13 \%$ to $70 \%$ of such days in the spring (Figure 5). If foods in brackish marshes were being fully utilized, such a pattern would be expected if more goosedays were spent on the Fraser River delta. Indeed, Figure 4 shows a predicted increase in goose days over time and the linear relation between annual goose days on agricultural fields and size of the Fraser-Skagit segment is significant $(P=0.002, r=0.83, \mathrm{df}=7)$; the lowest proportion of field-use occurred when the least number of goose days were spent on the Fraser River delta (1989-1990; Figures 4 and 5).

\section{Snow Geese and the Brackish Marsh}

The brackish marshes of the Fraser River delta are probably being over-utilized by Snow Geese. Model results indicate that the Fraser-Skagit segment exists at current levels only because the geese can also forage in upland fields. Maintaining numbers of Snow Goose above the carrying capacity of brackish marshes by way of providing supplemental feed on refuges and agricultural fields may degrade or continue to suppress the productivity of the brackish marshes. Boyd (1995) suspected that grubbing pressure by Snow Geese on 


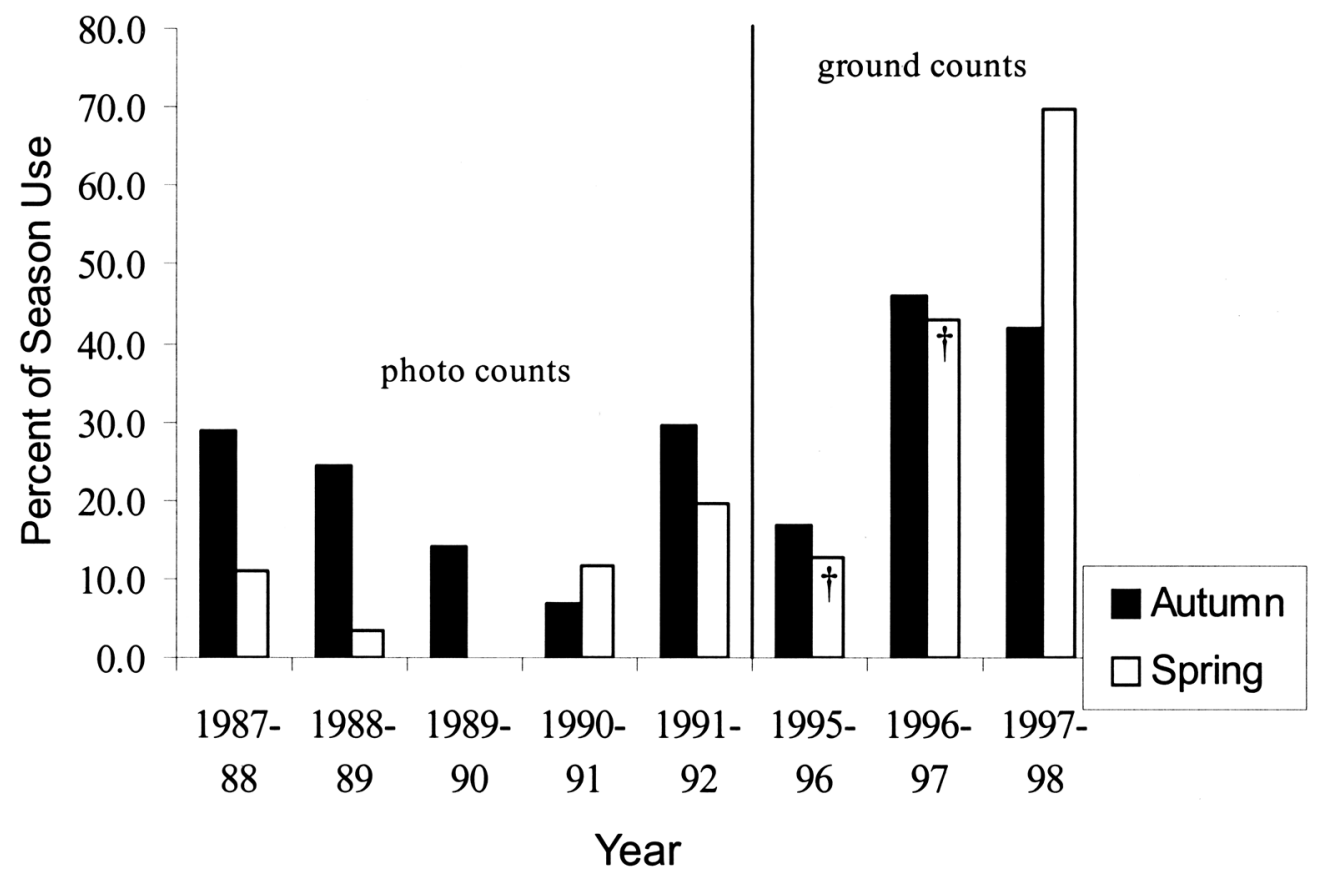

FIGURE 5. The estimated percentage of total Snow Goose-days on the Fraser River delta spent on agricultural fields during the "autumn" and "spring” seasons. Source: 1987-1992, Boyd (1995); 1995-1998, Canadian Wildlife Service et al. (1999*). $†$ Spring use in 1995-1997 is likely underestimated because surveys ended several weeks before spring migration (departure).

parts of the Fraser Delta was contributing to a reversal in marsh succession. Boyd (1995) also speculated that the reason that production in the brackish marshes of the Skagit River delta was even lower (i.e., 10\%) than the $15 \%$ figure reported for the Fraser River delta was because the Skagit River delta supported about twice as many goose-days as did the Fraser River delta during 1987-1992. Further, there is some concern that in recent years a greater proportion of the Wrangel Island population has been overwintering on the Fraser and Skagit deltas (Pacific Flyway Council 2006*).

If Snow Geese were excluded from all agricultural fields, including the sanctuary on Reifel and Westham islands, the segment would likely decline to a habitatlimited maximum size of $\sim 15000-20000$ birds. Although that scenario may be unrealistic, it is possible that changing land-uses and agricultural practices throughout the Wrangel Island population's winter range, in addition to changes in farmers' tolerance of Snow Geese in their fields, could direct even more foraging pressure onto brackish marshes. Regardless of farm-field availability, brackish marshes will always be vital for Snow Geese because during extended periods of freezing, the marshes are used exclusively (Boyd 1995). Use of marshes during cold weather likely reflects difficulties geese experience in obtaining food from the frozen or snow-covered soil of agricultural fields.

\section{Snow Geese and Agricultural Fields}

Forage from agricultural fields has contributed to the improved survivorship and subsequent population growth of Snow Geese in other parts of North America (Ankney 1996; Jeffries 1997). Possible reasons for the onset of, and increased use of, upland fields by Snow Geese on the Fraser River delta are not known with certainty, but it is plausible that rapid increases in the Snow Goose population during the late 1970s were largely responsible (Figure 3).

Burton (1977) predicted that if the Fraser-Skagit Snow Goose segment expanded beyond $\sim 20000$ birds, the brackish marshes of the Fraser River delta would be adversely affected. Although estimates of S. americanus biomass in the mid 1970s (Burton 1977) and in the early 1990s (Boyd 1995) are not directly comparable due to different sampling strategies, a general review of the datasets suggests that rhizome densities during the early 1990s likely approximated those during the mid 1970s. This suggests that the brackish marshes were already being used to capacity by Snow Geese prior to the onset of farm-field use. Unfortunately, there are no data documenting trends in S. americanus biomass immediately following the rise in Snow 
Goose numbers and onset of field use in the late 1970s and early 1980 s so it is not known whether S. americanus biomass declined under more foraging pressure then merely rebounded as incremental foraging pressure on the delta shifted to upland fields.

The increased use of agricultural fields by the geese supports the hypothesis that the brackish marshes alone could not sustain the increased foraging pressure that a rising Fraser-Skagit segment was putting on the Fraser River delta. If the geese could not meet their energetic demands in brackish marshes, they would have been forced to explore alternate food sources such as those in agricultural fields. Several lines of evidence support this hypothesis.

First, from the perspective of Snow Goose foraging habitat, agricultural production suitable for Snow Geese in the local area has probably declined since the 1970 s, both in areal extent and crop type (Boyd 1995). So, contrary to what might be expected, little or no use occurred when agricultural habitats were better for Snow Geese. According to W. Temple (DWFT, personal communication), there is no evidence that agricultural changes on the Fraser River delta influenced the initial use of upland habitats by Snow Geese in the late 1970 s and early 1980s. W. Temple (personal communication) indicated that crops that Snow Geese presently use were grown for many years before the birds started using them. In 1993, farming of corn, peas, and beans by commercial processors on the Fraser River delta was largely halted (W. Temple, personal communication); thereby further diminishing the area of agricultural fields suitable for foraging Snow Geese. This likely put increased foraging pressure on other fields, and perhaps, on the brackish marshes.

Second, S. americanus stands in the Fraser River delta are at about $15 \%$ of their biomass potential in the absence of grubbing by Snow Geese (Boyd 1995). This suggests that the brackish marshes are not producing vast amounts of unutilized rhizomatous foods. Assuming a "steady state" between rhizome production and consumption, as reported by Boyd (1995), brackish marshes are being fully utilized (even overutilized) by consumers such as Snow Geese.

Third, Snow Geese on the Fraser River delta exhibit a high degree of site fidelity (Burton 1977; Boyd 1995). Thus, the full or partial abandonment of an area could indicate decreased habitat suitability. A lack of food in the traditionally used brackish marshes is a plausible reason why Snow Geese explored upland feeding areas. Such exploratory behaviour was predicted by Burton (1977) before the segment increased and before agricultural fields were used by the geese.

Finally, speculation that changes to hunting seasons and hunting areas in the Fraser River delta forced Snow Geese to use upland fields beginning in the late 1970s is not supported. The existence of a waterfowl refuge on Reifel Island has conceivably provided Snow Geese with upland foraging opportunities free of hunting pressure since the 1960 s. Further evidence that hunting did not precipitate field use by Snow Geese is provided by Trumpeter Swans (Cygnus buccinator); a protected (i.e., unhunted) species since the 1930s. Trumpeter Swans and Snow Geese have similar diets during winter (Boyd 1995; Carter 1997). Trumpeter Swans have also experienced substantial increases in over-wintering populations in recent years. Carter (1997) noted that as numbers of Trumpeter Swans wintering near southwestern British Columbia have increased since the early $1970 \mathrm{~s}$, there has been a recent shift in habitat use from brackish marshes to agricultural areas. G. Fowler (CVWMP, personal communication) indicated that the use of agricultural fields by Trumpeter Swans in the Comox Valley on Vancouver Island, British Columbia, began in the mid-1970s. The onset of swan use of upland habitats was unlikely a response to any refuge effects provided by fields, as hunting for other waterfowl continues to this day on the same farm fields used by swans. Further, if swans were seeking refuge, the Courtenay River estuary (their traditional brackishmarsh wintering ground that has been largely abandoned as a foraging area in favour of upland sites) should still be used for foraging because it has been a no-shooting area since 1994 . The swans roost in the estuary, but minimal feeding occurs there (G. Fowler, personal communication).

\section{Conclusions}

Currently, the increasing numbers of Snow Geese wintering on the Fraser River delta $(\sim 80000$ in 20042005; Pacific Flyway Council 2006*) exceed the modelled autumn carrying capacity of the area's brackish marshes $(\sim 17500)$ by a large margin. As a result, the geese are highly dependent on forage provided in nearby agricultural and refuge fields. Despite compelling evidence that Snow Geese were grubbing $S$. americanus biomass to $\sim 15 \%$ of its biomass potential since at least the early 1990s (Boyd 1995) and a doubling of the Fraser-Skagit segment from 1995-2005, the 2006 management plan (Pacific Flyway Council 2006*) only states that increasing numbers of Snow Geese may be reducing the biomass and extent of $S$. americanus. The Pacific Flyway Council (2006* page 13) recommends researching the "trends in biomass and growth dynamics of American Bulrush, impacts of grubbing by Snow Geese on intertidal marshes, and the carrying capacity of the Fraser-Skagit." The current plan relies on hunting to regulate the Wrangel Island population once it exceeds a 3-y average of 160000 birds (Pacific Flyway Council 2006* page 32). As society's values and interests have shifted, sales of migratory bird hunting permits and participation in waterfowl hunting in British Columbia have declined steadily from 19742003 (Environment Canada 2005*). Hunting opportunity on the Fraser River delta has also diminished over time. Consequently, it is questionable that managers will be able to rely solely on hunting as a tool to effectively manage Snow Geese on the Fraser delta in the future. 
Given that the brackish marshes are currently being used to (present) carrying capacity, any further increases in the Fraser-Skagit segment will likely require: (1) a substantial increase in the production of S. americanus rhizomes, (2) a concomitant increase in the use of agricultural fields by the geese, (3) natural selection for lower adult body weights, and thus lower gross energetic demands, or (4) a combination of these. Recognizing the reduced production of the brackish marsh, Boyd (1995) recommended that consideration be given to increasing the productivity of $S$. americanus by applying fertilizer. However, unless fertilization results in a yield of rhizomes exceeding that which Snow Geese could potentially consume, there is no reason to believe that Snow Geese would not consume fertilizer-induced growth back down to the "steadystate". The current management plan (Pacific Flyway Council 2006*) does not identify a need to research ways of increasing the carrying capacity of the marsh as was recommended in the 1992 plan (Subcommittee on White Geese 1992*).

By serving as food for herbivores and detritivores and as structural habitat (cover) for fish and invertebrates, healthy brackish marshes in the Fraser River delta are integral to an ecosystem that supports such key animals as White Sturgeon, Pacific Eulachon, Pacific salmon, shorebirds, and Snow Geese among many others. Large numbers of Snow Goose have negative implications not only for the brackish marsh ecosystem, but also for human safety. Bird hazard evaluations have concluded that Snow Geese pose an extreme hazard to civilian aircraft at the Vancouver International Airport on Sea Island (Demarchi and Searing 1995*). Consequently, an aggressive Snow Goose control program is necessary each winter near Sea Island to mitigate that hazard.

A prudent approach to managing the Wrangel Island population of Lesser Snow Geese would, at a minimum, be sensitive to Snow Goose conservation, potential adverse effects of Snow Geese on the brackish marsh ecosystem, and the interactions between Snow Geese and agriculture, air-traffic safety, and other land uses in the Fraser River delta.

\section{Acknowledgments}

Many people made important contributions to this study and manuscript. Their assistance is greatly appreciated, but such assistance does not necessarily connote full agreement with the manuscript's conclusions. S. Boyd, Canadian Wildlife Service (CWS) provided important data and reviewed drafts of this manuscript. K. Moore and M. Porter, CWS, also provided important data (Canadian Wildlife Service et al. 1999). S. Smith, Delta Farmland and Wildlife Trust (DFWT), provided data. W. Temple, DFWT, provided information about agriculture. C. Levings, Department of Fisheries and Oceans and I. Hutchinson, Simon Fraser University, provided information and advice on brackish marshes in the Fraser River delta. R. Alisauskas, CWS, provided information on the current status of bioenergetic studies of Lesser Snow Geese and gave constructive feedback on the simulation model. R. Trost, U. S. Fish and Wildlife Service, provided information about the Pacific Flyway Management Plan. G. Fowler, Comox Valley Waterfowl Management Project, provided information about Trumpeter Swans in the Comox Valley. D. Kraege, U. S. Fish and Wildlife Service, reviewed drafts of this manuscript. S. Johnson and G. Searing, LGL Limited, contributed to the design of this assessment and reviewed a draft of this manuscript. R. Tamasi, LGL Limited, assisted with GIS and mapping. G. Glova, LGL Limited, reviewed a draft of this manuscript as did A. Erskine and an anonymous reviewer.

Documents Cited [marked * in text citations]

Canadian Wildlife Service, Ducks Unlimited, and the British Columbia Waterfowl Society. 1999. Westham Island winter waterfowl surveys 1995-1998. Unpublished data. Delta, British Columbia.

Demarchi, M. W., and G. F. Searing. 1995. Avian ecology and air-traffic safety at Vancouver International Airport. Unpublished report for Transport Canada, Ottawa, Ontario. 100 pages. Available from University of British Columbia Library.

Environment Canada. 2005. Data accessed via the INTERNET. http://www.ecoinfo.org/env_ind/region/ducks/ducks_ data_e.cfm\#Graph2 Last updated 14 June 2005.

Pacific Flyway Council. 2006. Pacific Flyway management plan for the Wrangel Island population of lesser snow geese. Revised Draft. White Goose Subcommittee, Pacific Flyway Study Committee. [c/o USFWS], 911 N.E. $11^{\text {th }}$ Avenue, Portland, Oregon. Accessed via the INTERNET. http:// pacificflyway.gov/Documents/Wilsg_plan.pdf

Smith, S. 1996. The Greenfields project 1995/96 historical database on cover crops. In The Greenfields Project 1995/ '96: an investigation of cover crops and waterfowl use in the Boundary Bay area. Edited by S. Smith. Unpublished report by the Delta Farmland and Wildlife Trust, Suite 205-4882 Delta Street Delta, British Columbia V4K 2 T8.

Subcommittee on White Geese. 1992. Pacific Flyway management plan for the Wrangel Island population of Lesser Snow Geese. Pacific Flyway Study Committee, Portland, Oregon. 25 pages.

Wetlands International. No date. A directory of wetlands of international importance: Canada Ramsar Site 243. Information accessed via the INTERNET. http://www.wetlands. org/RSDB/_COP9Directory/Directory/4CA009.html

\section{Literature Cited}

Ankney, C. D. 1996. An embarrassment of riches: too many geese. Journal of Wildlife Management 60: 217-223.

Boyd, W. S. 1995. Lesser Snow Geese (Anser C. caerulescens) and American Three-square Bulrush (Scirpus americanus) on the Fraser and Skagit River deltas. Ph. D. dissertation, Simon Fraser University, Burnaby, British Columbia. 154 pages.

Burton, B. A. 1977. Some aspects of the ecology of Lesser Snow Geese wintering on the Fraser River delta tidal marshes. M.Sc. thesis, University of British Columbia, Vancouver, British Columbia. 173 pages. 
Burton, B. A., R. J. Hudson, and D. D. Bragg. 1979. Efficiency of utilization of bulrush rhizomes by Lesser Snow Geese. Journal of Wildlife Management 43: 728-735.

Butler, R. W. and R. W. Campbell. 1987. The birds of the Fraser River delta: populations, ecology and international significance. Occasional Paper 65. Canadian Wildlife Service, Ottawa, Ontario. 73 pages.

Campbell R. W., N. K. Dawe, I. McTaggart-Cowan, J. M. Cooper, G. Kaiser, M. C. E. McNall. Editors. 1990. The birds of British Columbia. Volume Two. Royal British Columbia Museum, Victoria, British Columbia. 636 pages.

Carter, B. P. 1997. Winter habitat use by Trumpeter Swans (Cygnus buccinator) in the Fraser River delta, British Columbia. M.Sc. thesis, Simon Fraser University, Burnaby, British Columbia. 80 pages.

Frederick, R. B., and E. E. Klaas. 1982. Resource use and behaviour of migrating Snow Geese. Journal of Wildlife Management 46: 601-614.

Frederick, R. B., W. R. Clark, and E. E. Klaas. 1987. Behaviour, energetics, and management of refuging waterfowl: a simulation model. Wildlife Monographs 96.

Hoos L. M., and G. A. Packman. 1974. The Fraser River Estuary: status of environmental knowledge to 1974. Fisheries and Marine Service, Pacific Environment Institute. Special Estuary Series, Number. 1.

Hutchinson, I. 1982. Vegetation-environment relations in a brackish marsh, Lulu Island, Richmond, B.C. Canadian Journal of Botany 60: 452-462.

Jeffries, R. L. 1997. Long-term damage to sub-arctic coastal ecosystems by geese: ecological indicators and measures of ecosystem dysfunction. Pages 151-165 in Disturbance and recovery in arctic lands. Edited by R. M. M. Crawford. Kluwer Academic Publishers, Netherlands.
Kerbes, R. H., P. M. Kotanen, and R. L. Jefferies. 1990. Destruction of wetland habitats by Lesser Snow Geese: a keystone species on the west coast of Hudson Bay. Journal of Applied Ecology 27: 242-258.

King, J. R. 1974. Seasonal allocation of time and energy resources in birds. Pages 4-70 in Avian energetics. Edited by R. A. Paynter. Nutall Ornithological Club, Cambridge.

McIlhenny, E. A. 1932. The blue goose in its winter habitat. Auk 49:279-306.

McKelvey R., M. Bousfield, A. Reed, V. V. Baranyuk, and R. Canniff. 1989. Preliminary results of the Lesser Snow Goose collaring program on the Alaksen National Wildlife Area 1986 and 1987. Canadian Wildlife Service Progress Note Number 183, Ottawa, Ontario. 5 pages.

Moody, A. I. 1978. Growth and distribution of the vegetation of a southern Fraser River delta marsh. M.Sc. thesis, University of British Columbia, Vancouver, British Columbia. 153 pages.

Sedinger, J. S., R. G. White, and J. Hupp. 1995. Metabolizability and partitioning of energy and protein in green plants by yearling Lesser Snow Geese. Condor 97: 116122.

Williams, T. D., E. G. Cooch, R. L. Jeffries, and F. Cooke. 1993. Environmental degradation, food limitation and reproductive output: juvenile survival in Lesser Snow Geese. Journal of Animal Ecology 62: 766-777.

Yamanaka, K. 1975. Primary productivity of the Fraser River delta foreshore: yield estimates of emergent vegetation. M.Sc. thesis, University of British Columbia, Vancouver, British Columbia. 133 pages.

Received 10 November 2005

Accepted 20 September 2006 


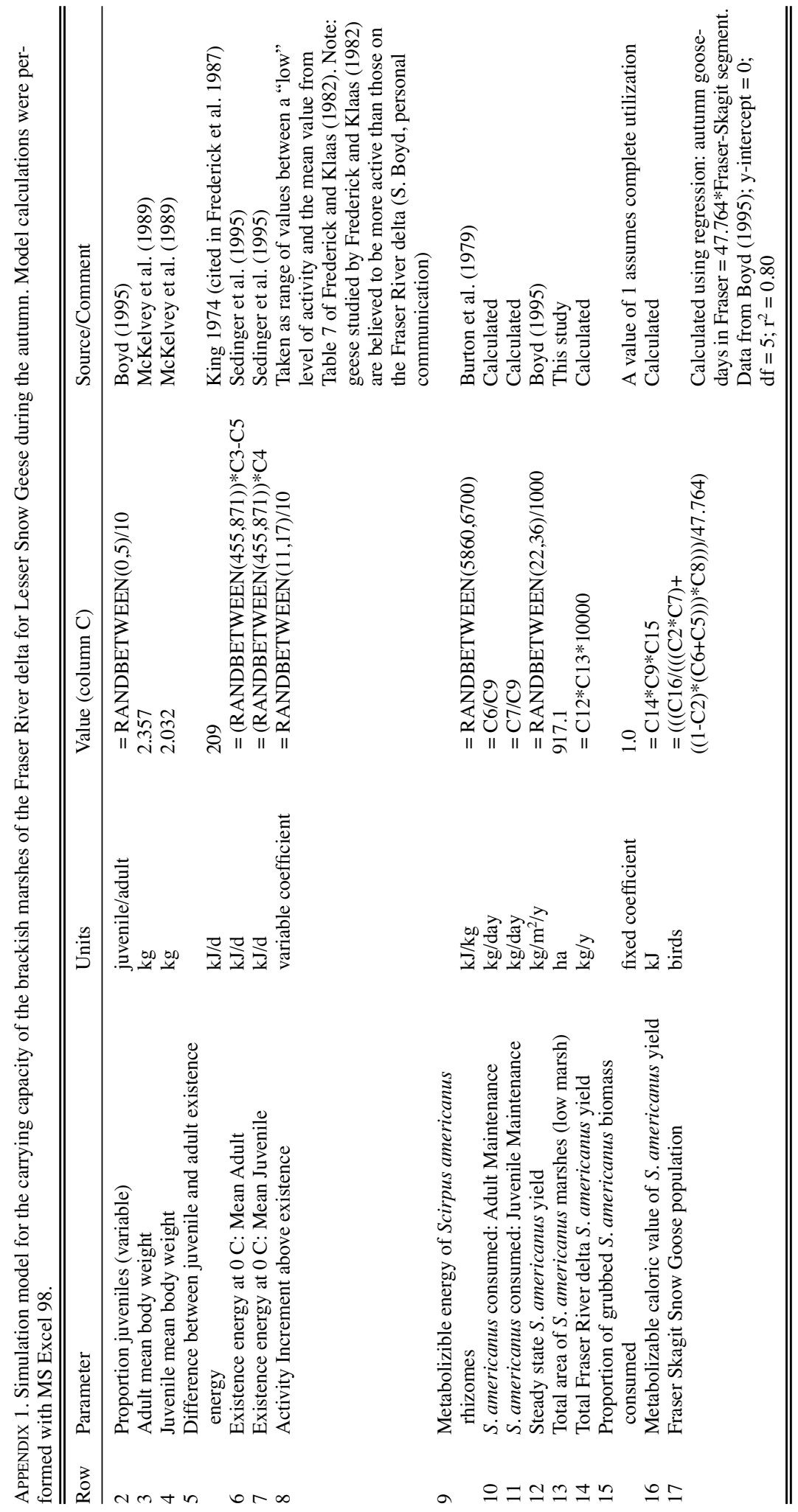




\section{ADDENDA}

\section{Last Flight?}

My third, and supposed final, flight of 10 November 2005 was in a De Havilland Dash 8 that was to take me home from a journey that began a few hours earlier in a 6-seat Piper Navaho that departed from a snowcovered gravel strip in northern B.C., then continued in a Bombardier CRJ from Prince George to Vancouver (YVR). The westbound departure from YVR's runway $26 \mathrm{~L}$ would take us over the marsh along the foreshore of Sea Island. It was like so many others I've been on since 1994 when I began studying bird-hazards to aircraft at YVR and helped develop their 24/7 wildlife control program to mitigate those hazards - many of which I had witnessed first-hand. There I was, wondering what critters might be flying around in the flight path this time. For night-time flights such as this, my usual thoughts turn to some poor, unsuspecting barn owl out patrolling the airfield in search of a plump vole. But this time a far more serious hazard was pondered: snow geese that breed in the Russian arctic and winter here by the tens of thousands. By chance, I had just submitted a manuscript for publication earlier in the week, addressing adverse effects of a burgeoning snow goose population on the Fraser Delta. And two days earlier on final approach I had spied a flock of geese loafing in the marsh near the flight path. I had heard recently that the wintering flock this year was bigger than ever.

With plenty of runway lights still below us, we levitated steeply into the darkness. By the time we were over the marsh, we'd reached an altitude that, based on my numerous hours of field-observations from a ground station near the runway's end, led me to believe that we had cleanly escaped the main bird-hazard zone yet again. Still, I peered out the right side at the faintly illuminated propeller hauling us into the blackness.

At some $300+\mathrm{km} / \mathrm{h}$ in the dark there was no chance for more than a glimpse of three or four whitish blurs, accompanied by subtle impact vibrations so transient that I can't remember if they were heard, felt, or both. Snow geese? Gulls? "Shit!" seemed like the right thing to say, so I did as I sat there with a helpless feeling wondering what, if any, damage had been done, and on tenterhooks bracing for more white blurs that, luckily, didn't appear.
As the craft began its usual roll toward Victoria I said to myself, "Okay, maybe I'm making this out to be a bigger deal than it is," thinking that my heightened awareness of bird hazards probably causes me to fret more than I should. Except this time, the turn continued a bit longer so that instead of heading over the Strait of Georgia, we were heading southeast over the lights of Delta. I knew something was amiss. Then the captain announced that we'd hit some birds and that we were going back to YVR for an "inspection". Well, at least the plane sounded okay and I couldn't see any evidence of severe damage like fire or smoke. Touchdown, taxi, stop, shutdown, back home - sort of.

Sitting on the apron and watching an aircraft mechanic inspect the wing, cowling, and what looked to be a bloodstained propeller (I surmised that blood does not show up so clearly on a black background) some questions arose. Can his flashlight look-see really pronounce the plane safe? Should I just grab my gear, walk off this plane and board another? Is it too late to catch a ferry? I sat there knowing that bird-strikes are not that uncommon and that by choice or not, the simple fact that I choose to fly means that I must have some faith in our air industry's standards and its technicians and mechanics. Besides, what could I know of the condition of any other aircraft in the fleet? When the captain announced that the plane was damaged and that we would have to deplane and board another, well, let's just say that I was not put out.

As deftly handled by the gate crew on what was already a very busy evening for regional air-travel out of Gate C38, within an half an hour 37 of the original 50 of us were lining up to board a shorter Dash 8 . The others might seek the calming benefit of a pint or two before catching their ride. On the way out of the covered walkway I engaged the ground crewman's humour about this time we should avoid the "shredded tweet"; taking it as a reference to the fact that this mustn't be a particularly unique event if it's got its own pun. Yet I must say that his humour was tempered somewhat by my second-hand knowledge of the deadly havoc a few birds can wreak when they strike the "wrong" parts of a fully loaded, outbound plane.

I'm happy to report the most exciting thing about the fourth of my supposed three plane rides that day was the "free" candy. Home safe (but a little shaken) in time for dinner. My next trip to YVR will be on Thursday. Faith be with me.

Mike W. Demarchi 12 November 2005 